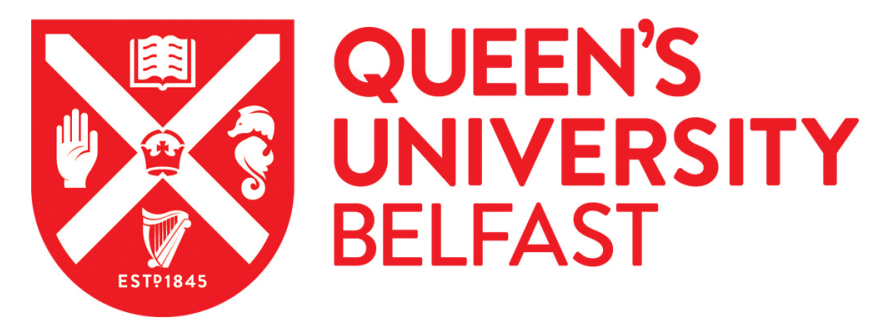

\title{
From Customer-Oriented Strategy to Organizational Financial Performance: The Role of Human Resource Management and Customer-Linking Capability
}

Lin, C-H., Sanders, K., Sun, J-M., Shipton, H., \& Mooi, E. A. (2016). From Customer-Oriented Strategy to Organizational Financial Performance: The Role of Human Resource Management and Customer-Linking Capability. British Journal of Management, 27(1), 21-37. https://doi.org/10.1111/1467-8551.12142

Published in:

British Journal of Management

Document Version:

Peer reviewed version

Queen's University Belfast - Research Portal:

Link to publication record in Queen's University Belfast Research Portal

\begin{abstract}
Publisher rights
(C) 2015 British Academy of Management

This is the peer reviewed version of the following article: Lin, C.-H., Sanders, K., Sun, J.-M., Shipton, H. and Mooi, E. A. (2016), From Customer-Oriented Strategy to Organizational Financial Performance: The Role of Human Resource Management and Customer-Linking Capability. British Journal of Management, 27: 21-37, which has been published in final form at

$\mathrm{http}: / /$ onlinelibrary. wiley.com/wol1/doi/10.1111/1467-8551.12142/abstract. This article may be used for non-commercial purposes in accordance with Wiley Terms and Conditions for Self-Archiving.

General rights

Copyright for the publications made accessible via the Queen's University Belfast Research Portal is retained by the author(s) and / or other copyright owners and it is a condition of accessing these publications that users recognise and abide by the legal requirements associated with these rights.
\end{abstract}

Take down policy

The Research Portal is Queen's institutional repository that provides access to Queen's research output. Every effort has been made to ensure that content in the Research Portal does not infringe any person's rights, or applicable UK laws. If you discover content in the Research Portal that you believe breaches copyright or violates any law, please contact openaccess@qub.ac.uk. 


\title{
From Customer-Oriented Strategy to Organizational Financial Performance: The
}

\section{Role of Human Resource Management and Customer-Linking Capability}

\author{
Cai-Hui (Veronica) Lin* \\ Nottingham Business School, Nottingham Trent University \\ E-mail: veronica.lin@ntu.ac.uk
}

Karin Sanders

School of Management, University of New South Wales Australia

Jian-Min (James) Sun

School of Labor and Human Resources and Department of Psychology, Renmin University of China

\section{Helen Shipton}

Nottingham Business School, Nottingham Trent University

Erik A. Mooi

Department of Management \& Marketing, The University of Melbourne

*Corresponding author.

\section{Author Biography}

CAI-HUI (VERONICA) LIN is a post-doctoral research fellow at Nottingham Business School, Nottingham Trent University. Cai-Hui's research focuses on strategic human resource management, creativity, innovation, and research methods in human resource management. Her work has been published in Research Methods for Human Resource Management by Routledge.

KARIN SANDERS, PhD, is Professor at the School of Management, UNSW Business School, Sydney, Australia. Her research focuses on the process approach of HRM, in particular the impact of employees' perceptions and attributions of HRM on their attitudes and behaviors. Her research has been published in such outlets as the Journal of Vocational Behavior, Organizational Studies, Academy of Management Learning \& Education, and Human Resource Management. She is associate editor of the International Journal of HRM.

JIAN-MIN (JAMES) SUN, PhD, is Professor of Management at the School of Labor and Human Resources and Chair of the Department of Psychology, Renmin University of China. His research focuses on strategic human resource management, individual attitudes and behaviors in organizations, leadership and cross-cultural management. He has published in such journals as Leadership Quarterly, International Journal of Human Resource Management, Journal of International Business Studies, and Strategic Management Journal, among others. 
HELEN SHIPTON is Professor of International HRM and Head of Doctoral Programmes at Nottingham Business School, Nottingham Trent University, United Kingdom. Helen was previously Senior Lecturer at Aston Business School, Birmingham, United Kingdom (20032013). Helen's research focuses on HRM, innovation and performance. Helen has published widely in leading peer-reviewed journals such as Human Resource Management, the International Journal of HRM, Journal of Organizational Behaviour, Journal of International Business Studies, and Human Resource Management Journal.

ERIK A. MOOI is senior lecturer at the University of Melbourne, Australia. His research mainly focuses on marketing strategy. He has published, amongst others, in the Journal of Marketing and the International Journal of Research in Marketing. He is also the author of $A$ Concise Guide to Market Research published by Springer.

\section{Acknowledgements}

We want to express our gratitude to Graham Hooley and his team for organising the data collection effort. Jian-Min Sun and Helen Shipton would like to acknowledge the UNSW Business School for the host of their academic visits to the school. These visits have enabled this collaboration. Karin Sanders would like to thank Nottingham Business School for hosting her visit to the school. This paper is based on part of Cai-Hui Lin's dissertation at the University of New South Wales Australia. 


\title{
From Customer-Oriented Strategy to Organizational Financial Performance: The Role of Human Resource Management and Customer-Linking Capability
}

\begin{abstract}
Drawing on the organizational capabilities literature, we developed and tested a model of how supportive human resource management (HRM) improved firms' financial performance perceived by marketing managers through fostering the implementation of a customer-oriented strategy. Customer-linking capability, which is the capability in managing close customer relationships, indicated the implementation of the customer-oriented strategy. Data collected from two emerging economies-China and Hungary-established that supportive HRM partially mediated the relationship between customer-oriented strategy and customer-linking capability. Customer-linking capability further explained how supportive HRM contributed to perceived financial performance. This study explicates the implication of customer-oriented strategy for HRM and reveals the importance of HRM in strategy implementation. It also sheds some light on the "black-box" between HRM and performance. While making important contributions to the field of strategy, HRM and marketing, this study also offers useful practical implications.
\end{abstract}

Keywords: strategy implementation, human resource management, customer-linking capability, perceived financial performance 


\section{HRM and Strategy Implementation}

Facing increasingly intense competition for market share, many firms have adopted a customer-oriented strategy. This strategy positions firms to stand out from their competitors through better satisfying customer needs and creating value for customers (Narver and Slater, 1990). Prominent firms that adopt such a strategy, such as Marriott, Xerox and Amazon, have realized that to fully release the value of a customer-oriented strategy, they need to mobilize its human resources (Noe, Hollenbeck, Gerhart and Wright, 2005; Ulrich, 1992). Therefore, they arrange their human resource management (HRM) accordingly. This bears testament to the assertion of HR scholars that the contribution of HRM to performance lies in its support for strategy implementation (Becker and Huselid, 2006; Huselid, Becker and Beatty, 2005). Human resources and their management arguably play a vital role in implementing customer-oriented strategy and creating satisfied customers, both in service and manufacturing sector (Liao and Subramony, 2008). Satisfied customers in turn result in higher organizational profits (Heskett, Sasser and Schlesinger, 2003).

To elucidate the perplexing question of how HRM can support a firm to implement its customer-oriented strategy and achieve high financial performance, most research has considered service climate (Hong, Liao, Hu and Jiang, 2013) and employee outcomes (Chuang and Liao, 2010; Nishii, Lepak and Schneider, 2008) as the intervening mechanisms. Different from these literatures, we derive our position from the organizational capabilities literature (e.g., Amit and Schoemaker, 1993; Barney, 1991; Helfat and Winter, 2011; Wernerfelt, 1984). Capabilities are valuable organizational resources. They derive substantially from organizational experiences and are "home grown" (Helfat and Winter, 2011; Makadok, 2001). Capabilities constitute a key dimension of firm heterogeneity (Helfat and Winter, 2011; Nelson and Winter, 1982) and account for differences in firm performance. In this study we focus on customer-linking capability, 


\section{HRM and Strategy Implementation}

defined as firm's capability in creating and maintaining close customer relationships (Day, 1994; Hooley, Greenley, Cadogan and Fahy, 2005; Rapp, Trainor and Agnihotri, 2010). Close customer relationships are viewed as intangible firm-specific resources (Rapp et al., 2010; Srivastava, Shervani and Fahey, 1998) and generate high profits for firms (Heskett et al., 2003; Storbacka, Strandvik and Grönroos, 1994). Firms’ capability in establishing and maintaining customer relationships (i.e., customer-linking capability) is asserted to be a key success factor for customer-oriented firms (Day, 1994; Deshpandé, Farley and Webster Jr, 1993).

Although well studied in the marketing literature (e.g., Krasnikov, Jayachandran and Kumar, 2009; Payne and Frow, 2005), there is a dearth of empirical research on customer-linking capability from an HRM perspective. Marketing scholars have stressed that interfunctional coordination is needed to create superior customer value (Narver and Slater, 1990). HR scholars also argue and have shown that HRM supports the development of various organizational capabilities (e.g., Kim and Lee, 2012; Lado and Wilson, 1994; Lopez-Cabrales, Valle and Herrero, 2006; Morris and Snell, 2011; Wei and Lau, 2010). Becker and Huselid (2006) further assert that building key organizational capabilities is an important way in which HRM impacts performance. Given the importance of customer-linking capability to firm performance and the established relationships between HRM and a number of organizational capabilities, there is a need to examine whether HRM enhances firms' customer-linking capability and thereby translates a customer-oriented strategy into financial performance.

This study aims to fill this gap. Based on the organizational capabilities theory, we investigate the role of HRM in converting a customer-oriented strategy into customer-linking capability and thereby improving financial performance perceived by marketing managers. In doing this, we also explicate the implications of customer-oriented strategy for HRM. With this 


\section{HRM and Strategy Implementation}

study we expect to make several contributions. First, it connects with growing interest in HRM's role in fostering strategy implementation (Becker and Huselid, 2006; Buller and McEvoy, 2012; Huselid et al., 2005) and contributes to the broader literature of strategy process (Hutzschenreuter and Kleindienst, 2006). In contrast to strategy formulation, which often involves only management, strategy implementation entails the involvement of employees in order to develop strategic capabilities to enact organizational goals, where HRM plays a central role (Buller and McEvoy, 2012; Paauwe, 2004).

Second, this study sheds light on how and why HRM develops customer-linking capability and adds value to organizational performance. Researchers assert that heterogeneity in HRM accounts for performance difference (Barney and Wright, 1998). Building on the organizational capabilities literature, we elaborate on how heterogeneity in HRM leads to heterogeneity in organizational capabilities. Organizational capabilities address the static problem in the original RBV (Helfat and Peteraf, 2003) and are claimed to be more critical to organizations than HRM itself (Park, Gardner and Wright, 2004). This study thus contributes to opening the "black box" between HRM and performance. Particularly, this study is one of the first to investigate customer-linking capability as a mediator between HRM and organizational financial performance.

Third, by investigating the implications of customer-oriented strategy for HRM, this study reinvigorates research on the antecedents of HRM. Strategy represents a firm's positioning within a competitive environment. It implies what kind of HRM and organizational capabilities are needed to accomplish organizational goals (Chadwick and Cappelli, 1999). However, the relationship between strategy and HRM has received less attention in recent years and researchers have called for more research on it (Zhao and Chadwick, 2014). Our study answers this call. 


\section{HRM and Strategy Implementation}

The remainder of this paper is organized as follows: First, relevant literature is reviewed and hypotheses are proposed. Second, the sampling, data collection procedures and results in two transitional economies-China and Hungary-are presented respectively. The paper concludes with a discussion of the theoretical and practical implications of this research, as well as its limitations.

\section{Theoretical Framework and Hypotheses}

In recent years it has been increasingly recognized that firms' ability to implement a strategy varies substantially and is, in itself, a valuable resource (Barney, 2001). Because a wisely made strategic choice has little value unless it is effectively implemented (Noble, 1999), there has been increased interest in the factors that determine the success of strategy implementation. HR scholars argue that HRM supports strategy implementation (Becker and Huselid, 2006; Huselid et al., 2005; Porter, 1985; Schuler and Jackson, 1987) or enables a range of strategic options (Paauwe, 2004). While the importance of HRM in strategy implementation has been broadly recognized, few studies have directly tested the role of HRM in strategy implementation. In most studies HRM is examined as a moderator between a generic positioning strategy (which is different from strategy implementation) and organizational performance (e.g., Guthrie, Spell and Nyamori, 2002; Youndt, Snell, Dean and Lepak, 1996). In other studies, the implication of a positioning strategy for HRM and performance was examined, without invoking the strategy implementation concept (e.g., Bae and Lawler, 2000; Camps and Luna-Arocas, 2012). The paucity of research explicitly addressing the role of HRM in strategy implementation has led Becker and Huselid (2006) to call for "a new emphasis on strategy implementation as the focal mediating construct in SHRM" (p. 899). Further, they propose organizational capabilities as appropriate operationalization of strategy implementation. 


\section{HRM and Strategy Implementation}

Organizational capabilities theory is an extension of the original RBV. The original RBV views heterogeneity in resource possession as fundamental in explaining firm performance. Resources that are rare, valuable, inimitable, and non-substitutable provide the basis for sustained competitive advantage (Barney, 1991; Wernerfelt, 1984). In contrast, organizational capabilities refer to "a firm's capacity to deploy resources, usually in combination, using organizational processes, to effect a desired end" (Amit and Schoemaker, 1993, italic added). In particular, organizational capabilities contain a dynamic element. The recombination and reconfiguration of resources may allow firms to address changing environment (Teece, Pisano and Shuen, 1997). Although in theory capabilities can be distinguished between operational and dynamic capabilities-the former maintains, while the latter alters the status quo, it is hard to draw a bright line between the two, because even operational capabilities may cause significant change over the long run and some capabilities may serve dual-purpose (Helfat and Winter, 2011).

The notion of capabilities has a close connection with strategy implementation. Capabilities are defined in relation to concrete business processes (Eisenhardt and Martin, 2000). They represent a firm's capacity to perform a particular activity in a reliable and at least minimally satisfactory fashion (Helfat et al., 2007; Helfat and Winter, 2011). Therefore, they are directly related to strategy implementation and could be its appropriate operationalization. On the contrary, simply choosing a generic strategic positioning does not imply its implementation or any particular capabilities (Barney, 2001; Porter, 1996). Because organizational capabilities are developed over time through interactions across a firm's resources, they are firm-specific and inimitable (Teece et al., 1997). Some proponents thus claim that capabilities are the "best" source of sustainable competitive advantage (Prahalad and Hamel, 1990; Treacy and Wiersema, 1993). 
HRM and Strategy Implementation

\section{Customer-oriented strategy and customer-linking capability}

Positioning strategy represents fundamental choices about organizational intentions to address environmental contingencies. It implies the capabilities and resources needed to realize these intentions (Chadwick and Cappelli, 1999). A customer-oriented strategy intends to create and capture value by satisfying customer needs better than their competitors. It extends the traditional product-centric logic by emphasizing the whole customer experience, from sale to maintenance and expansion (Davenport, Harris and Kohli, 2001). In order to realize this strategic intention, firms need to keep the quality of their products and services at a satisfactory level and be responsive to customer needs (Ruekert, 1992). Customer-linking capability is essential in this process.

Customer-linking capability refers to a firm's ability to create, maintain and enhance intimate relationships or "bonds" with customers (Hooley et al., 2005). The emphasis on customer relationships within marketing started in 1980 s when the marketing paradigm began to shift from a goods-dominant view towards a service-dominant view (Berry, 1983; Grönroos, 1994; Gummesson, 1994). The former paradigm emphasizes tangible goods and marketing activities that add utility to the goods, whereas in the latter paradigm intangible exchange processes and relationships are central (Harker and Egan, 2006; Vargo and Lusch, 2004). Marketing researchers realize that relationships have a major impact on customer perceived value of purchase and their satisfaction. Long-lasting customer relationships on one hand give firms the opportunity to systematically collect customer information through repeated interactions. This allows firms to develop deep understanding of customer needs and improve their products and services to satisfy these needs (Mithas, Krishnan and Fornell, 2005). On the other hand, customer relationships provide unique interpersonal value for customers (Payne and Holt, 2001). Long- 


\section{HRM and Strategy Implementation}

term relationships signal an organization's loyalty to its customers and engender trust on the side of customers (Gremler, Gwinner and Brown, 2001).

Because a crucial dimension of strategy is its intentionality, that is, organizational actors have discretions to act strategically towards a goal (Chadwick and Cappelli, 1999), strategy would significantly influence an organization's resource allocation. Directed by a customer-oriented strategy, firms are likely to intentionally allocate resources in favour of customers. Given the accumulated evidence on the importance of customer relationships in delivering customer value, we expect that firms adopting a customer-oriented strategy would allocate their resources toward building customer-linking capability and thus possess higher such capability. Formally:

\section{H1: A firm's customer-oriented strategy is positively related to its customer-linking} capability.

\section{HRM as a mediator between customer-oriented strategy and customer-linking capability}

A customer-oriented strategy does not automatically turn into customer-linking capability. Employees are the actors that ultimately implement a firm's strategy. Both front-line and backstage employees engage in generating good customer relationships and creating satisfied customers (Swift, 2000). Although the front-line employees might have a more direct effect, backstage employees also influence customer relationships by affecting the quality of the products and providing reliable support to front-line employees (Levitt, 1969; Liao and Subramony, 2008). For instance, the relationship between a hotel and a hotel guest is not only determined by the receptionist who comes into direct contact with the guest. The cleaner can also influence the relationship in an indirect way. If the hotel room is not clean, the customer might terminate the relationship with the hotel, however good the receptionist's service is. Thus, to 


\section{HRM and Strategy Implementation}

successfully implement a customer-oriented strategy and develop customer-linking capability, both frontline and backstage employees need to be mobilized.

Supportive HRM practices, which are HRM practices that take care of employees' well-being and facilitate their task completion, may well support a customer-oriented strategy. Researchers and practitioners have long argued that customer satisfaction is premised by employee satisfaction (Nishii et al., 2008; Schneider and Bowen, 1985; Ulrich, 1992). A meta-analysis further corroborates this statement by finding a positive correlation of .32 between employee and customer satisfaction based on a large sample (Harter, Schmidt and Hayes, 2002). Organizational support is essential to attaining employee satisfaction, as it signals that organization values employees' contribution and cares about their well-being (Einsenberger, Cummings, Aemeli and Lynch, 1997; Riggle, Edmondson and Hansen, 2009). Supportive HRM practices can communicate these values (Allen, Shore and Griffeth, 2003). For example, performance appraisals which have a developmental instead of evaluative focus imply organizational investment in employees' growth and development and solicit employee cooperation (Boswell and Boudreau, 2002). Employee communication practices such as regular staff meetings provide opportunities for employees' input and participation in decision-making (Smidts, Pruyn and Van Riel, 2001). Similarly, managers' enquiries of employees' feelings about their work and attitude surveys show management's receptiveness to employee voices. Feeling supported by the organization and satisfied with their work environment, employees will exhibit pro-social behaviours (Nishii et al., 2008). In customer-oriented firms, these behaviours are likely to be exhibited as helping behaviours towards customers. Furthermore, these practices can assist employees in completing their tasks by identifying areas for individual and organizational improvement. For instance, in developmental performance appraisal, the competencies and skills 


\section{HRM and Strategy Implementation}

needed to support customers can be identified and corresponding developmental support can be provided. At staff meetings issues of dealing with customer complaints or improving product features can be discussed. Thus, supportive HRM provides a good fit with the customer-oriented strategy.

Employee perceived support and satisfaction are essential to the development of customerlinking capability. Customer-linking capability entails gaining deep understanding of customer needs through extensive communication and satisfying these needs through products and service (Day, 1994; Rapp et al., 2010). Although nowadays technology is extensively used to collect transaction data, this should be complemented by "human" data, which is the data collected through communication with customers (Davenport et al., 2001). Satisfied employees are more likely to proactively engage with customers, probe customer needs and provide better service (Schneider and Bowen, 1995; Schneider et al., 2005; Schneider, White and Paul, 1998). In companies which truly understand the customers, data collected from customers is further passed on to engineers and product developer for analysis (Davenport et al., 2001). Supportive HRM practices also motivate and help these backstage employees to complete their tasks, which ultimately serve to satisfy the customers and enhance customer relationships.

Like any other organizational capability, the development of customer-linking capability entails the recombination of multiple resources (Makadok, 2001). However, because other resources (such as technology) by themselves are incapably of managing customer relationships (Rigby, Reichheld and Schefter, 2002), human resource-the only resource that has free will-must be mobilized (Chadwick and Dabu, 2009). Supportive HRM provides a good fit with the customer-oriented strategy and is essential to the development of customer-linking capability. We 


\section{HRM and Strategy Implementation}

expect that it will help to turn customer-oriented strategy into customer-linking capability. Therefore, we propose:

H2: Supportive HRM mediates the relationship between customer-oriented strategy and customer-linking capability.

\section{Customer-linking capability and organizational financial performance}

In the term of Helfat and Winter (2011), customer-linking capability may serve "dualpurpose" of being operational and dynamic capabilities. On the one hand, maintaining and enhancing relationships with existing customers retains a firm's current customer base and enables a firm to continue the way it makes a living. On the other hand, tracking the evolving needs of existing customers through established relationships and creating relationships with new customers allows a firm to develop better products and services and generate new sources of income (Davenport et al., 2001; Nambisan, 2002).

Through an organizational capabilities theory lens, the formation of customer-linking capability is causally ambiguous (Guenzi and Troilo, 2006; Rapp et al., 2010). Although it is known that the development of customer-linking capability relies on multiple resources including human resources, the configuration of these resources is less clear. Also, much flexibility is needed in dealing with customer requirements. What constitutes good customer-linking practices may not be clearly articulated or fully specified, but relies on shared understanding or experiences within an organization (Gibbons and Henderson, 2012). Good customer relationships are also cultivated over a long time. Customers likely only develop trust in a firm after repeated transactions. These features of customer-linking capability mean that it cannot be easily imitated, at least not within a short time. The dynamic component of customer-linking capability further 


\section{HRM and Strategy Implementation}

confers firms the ability to capture changing customer needs and reconfigure its products and services to counterbalance the negative effects of environmental dynamism (Ambrosini, Bowman and Collier, 2009; Easterby-Smith, Lyles and Peteraf, 2009). Therefore, we propose that customer-linking capability has the potential to create sustained competitive advantage and contribute to a firm's bottom line.

H3: A firm's customer-linking capability is positively related to its financial performance.

\section{Customer-linking capability as a mediator between HRM and financial performance}

Given the relationship between supportive HRM and customer-linking capability and that between customer-linking capability and financial performance, we further propose that customer-linking capability serves as an intermediary linkage between supportive HRM and financial performance. Supportive HRM elicits appropriate employee attitudes and behaviours which constitute the micro-foundations of customer-linking capability. Customer-linking capability in turn secures existing customers and creates new customers for firms to derive profits (Davenport et al., 2001). Without customer-linking capability, supportive HRM practices might not directly contribute to financial performance. Instead, because customers are the ultimate source of firm incomes (Heskett et al., 2003), supportive HRM likely contributes to financial performance by developing firms' customer-facing capabilities.

Although various mechanisms have been explored to explain the relationship between HRM and financial bottom line (Lepak, Takeuchi, Erhardt and Colakoglu, 2006), customer-linking capability has not been investigated despite its well-recorded contribution to financial outcomes in the marketing literature (Storbacka et al., 1994). Integrating the HRM and marketing literature, we propose: 


\section{HRM and Strategy Implementation}

H4: Customer-linking capability mediates the relationship between supportive HRM and financial performance.

\section{Study 1 Methods}

The context of our first study was set in China, arguably the most important transition economy. The dynamism of the transition economy means that firms must confront changing customer needs and new competition. Additionally, the business environment in transition economies is less stable. This might force firms to rely more on relationships to retain and obtain customers than anywhere else. A comparative study on mainland China and Hong Kong revealed that a relationship marketing orientation was more effective in mainland China due to its unstable political, legal and bureaucratic conditions (Sin et al., 2005). Therefore, customer-linking capability should be highly relevant to this context.

\section{Sample and data collection procedure}

Data used for this study were collected from Chinese firms as part of a large-scale project "Marketing in the $21^{\text {st }}$ Century". The Dun and Bradstreet Directory of Chinese Companies was used as a sampling frame. The researchers then developed a stratified sampling approach, based on firm size, industry and market type for firms operating in China. Firms were categorized into small (20-99 employees), medium (100-499 employees), and large (500 or more employees) firms. Not-for-profit firms and firms with fewer than 20 employees were excluded. They operate in a broad economic cross-section that includes banking, telecommunication, information technology, pharmaceutical manufacturing, automotive production, energy and shipping. From the sampling plan firms were selected randomly, contacted, and asked to provide details on the person in charge of marketing. This person, often the chief marketing officer or marketing 


\section{HRM and Strategy Implementation}

director, was subsequently called, briefed on the study, and asked to participate. Upon agreement a questionnaire was sent. In cases where the marketing specialist was not available, the chief executive officer or general manager was asked to respond. After two weeks, a follow-up survey was sent if no response has been obtained. Confidentiality was assured to each participant to increase response rates and to avoid potential biases. Responses from 361 firms were received, representing a response rate of $25 \%$. After omitting firms with too many missing data, 349 firms were retained in the sample.

\section{Measures}

All the measures were originally developed in English. Translation and back-translation procedures (Brislin, 1970) were followed to make sure that the Chinese measures were equivalent to the original English measures. Except for customer-oriented strategy which was measured on a seven-point Likert scale, all the other three constructs were measured on five-point Likert scales. All measures could be found in the Appendix.

Customer-oriented strategy. Five items developed by Narver and Slater (1990) were used to measure customer-oriented strategy. A sample item was "Our objectives and strategies are driven by the creation of customer satisfaction". Respondents were asked to rate the extent to which the descriptions characterize their organization $(1=$ "not at all", $7=$ "to a great extent"). The internal reliability coefficient (Cronbach's alpha) of this scale was .73.

Supportive HRM. Four items from Greenley and Foxall (1997) were used to measure supportive HRM. The same items have been used in Greenley, Hooley, and Rudd (2005) to tap into a firm's employee orientation. It covered developmental performance appraisal and multiple employee communication practices. Respondents were asked to rate the extent to which they 
agreed with the statements provided. The responses ranged from $1=$ "strongly disagree" to $5=$ “strongly agree”. Cronbach’s alpha of this scale was .74.

Customer-linking capability was measured by asking the respondents to what extent managing customer relationships were their advantage relative to competitors. The scale was derived from the theoretical work of Day (1994) and consisted of three items. The responses ranged from 1 = “strong competitor's advantage" to $5=$ “our strong advantage". Rating firm's capabilities in relative advantage to competitors is well accepted in the strategy literature (e.g., Danneels, 2008; Denrell, Arvidsson and Zander, 2004). Cronbach's alpha of this scale was .76.

Financial performance was measured using three items. Respondents rated their firm's profit level, profit margins and return on investment relative to those of their main competitors. The responses ranged from $1=$ "much worse" to $5=$ "much better". A subjective measure of financial performance was adopted because objective information was not available. In addition, because the sampled firms reside in different industries, their financial performance might not be comparable. An empirical study demonstrated the convergent validity of subjective measures with objective measures of organizational performance (Wall et al., 2004). Cronbach's alpha of this scale was .86 .

\section{Analytical approaches}

We employed structural equation modeling (SEM) to test the theoretical model using MPlus (Muthén and Muthén, 1998-2010). SEM can simultaneously take the measurement and structural models into account and yields overall fit indexes of the hypothesized and alternative models (James and Brett, 1984). A bootstrapping method was used to cross-validate the SEM findings. 


\section{HRM and Strategy Implementation}

We adopted the two-step SEM outlined in Anderson and Gerbing's (1988) by first testing the measurement model and then assessing the fit of the structural model.

\section{Descriptive results}

\section{Study 1 Results}

Table 1 presents descriptive statistics, zero-order correlations, and scale reliabilities of the variables in this study. Customer-oriented strategy was associated with customer-linking capability $(\mathrm{r}=.27, \mathrm{p}<.01)$ and HRM $(\mathrm{r}=.20, \mathrm{p}<.01)$. HRM was associated with customerlinking capability $(\mathrm{r}=.19, \mathrm{p}<.01)$, but not with financial performance $(\mathrm{r}=.05, \mathrm{n} . \mathrm{s}$.$) . Customer-$ linking capability were associated with financial performance $(\mathrm{r}=.17, \mathrm{p}<.01)$.

Table 1 Summary statistics, zero-order correlations, and reliabilities for the Chinese sample

\begin{tabular}{lllllll}
\hline Variable & Mean & SD & 1 & 2 & 3 & 4 \\
\hline 1.Customer-oriented strategy & 4.88 & .93 & $(.73)$ & & & \\
2. Supportive HRM & 4.03 & .55 & $.20^{* *}$ & $(.74)$ & & \\
3. Customer-linking capability & 3.89 & .67 & $.27^{* *}$ & $.19^{* *}$ & $(.76)$ & \\
4. Financial performance & 3.82 & .79 & .08 & .05 & $.17^{* *}$ & $(.86)$ \\
\hline
\end{tabular}

Notes: $\mathrm{N}=349$.

Internal reliabilities (Cronbach's Alpha) for the constructs are given in parentheses on the diagonal.

${ }^{* *} \mathrm{p}<.01,{ }^{*} \mathrm{p}<.05$, two-tailed.

\section{Common method variance}

Because the data were reported by the marketing officers at one time point, the potential for common method variance exists. Precautions were taken against this when designing this questionnaire. The independent and mediating variables were positioned before the dependent variables to reduce the effects of consistency artefact (Salancik and Pfeffer, 1977). In addition, the measures were dispersed in the questionnaire which also included other organizational practices, so inference of causal relationship was less easy. Following Podsakoff, MacKenzie, 


\section{HRM and Strategy Implementation}

Lee, and Podsakoff (2003), we performed an EFA without rotation using Harman's single-factor test: Four factors emerged and the first factor explained $23.09 \%$ of the variance. No dominant factor explains the majority of the variance.

To provide further evidence, we employed the marker variable technique of Lindell and Whitney (2001). This method requires including a scale that is theoretically irrelevant to at least one scale in the questionnaire. Zero correlations between the items of the two scales are expected. The smallest correlation between the items of the two scales then would provide a reasonable proxy for the method effect. We chose the pricing activities of a firm as the marker variables, because the strategy a firm uses to set prices of its products and services is unlikely to correlate with its HRM. The pricing activities scale included two items: "We set prices based on what the market is prepared to pay" and "We set prices on the basis of costs of producing plus a fixed margin for profit". An examination of the correlations between the two items of pricing activities and the four items of supportive HRM revealed that the smallest correlation was .05 and nonsignificant. Therefore, we conclude that common method variance is unlikely to inflate the relationships found in this study.

\section{Measurement model}

The measurement model consisted of four latent constructs (customer-oriented strategy, supportive HRM, customer-linking capability and financial performance). The fit indexes indicated that the four-factor measurement model had good fit $\left(\chi_{(84)}^{2}=100.60, p>.05\right.$, CFI $=.990, \mathrm{TLI}=.987, \mathrm{RMSEA}=.024, \mathrm{SRMR}=.041)$. All indicators loaded on their respective constructs as proposed at the .001 level, providing evidence for convergent validity. The fit indices of the one-factor model were significantly worse than the four-factor model $\left(\chi_{(90)}^{2}=\right.$ 
$1,102.41, \mathrm{p}<.01, \mathrm{CFI}=.365, \mathrm{TLI}=.259, \mathrm{RMSEA}=.180, \mathrm{SRMR}=.156, \Delta \chi_{(6)}^{2}=1,001.81, \mathrm{p}$ $<.01$ ), providing support for the discriminant validity of the constructs. These findings suggested that further examination of the hypothesized model was warranted.

\section{Structural model}

We generated a structural model based on our theoretical framework and then compared it with an alternative model. Structural modelling results suggested that the hypothesized model fitted the data well: $\left(\chi^{2}{ }_{(87)}=117.05, \mathrm{p}<.05, \mathrm{CFI}=.981, \mathrm{TLI}=.977, \mathrm{RMSEA}=.031, \mathrm{SRMR}\right.$ $=.058)$. The alternative model is a partial mediation model in which supportive HRM partially mediates the relationship between customer-oriented strategy and customer-linking capability. This alternative model recognizes that strategy implementation requires the mobilization of multiple resources. It is also consistent with the theorization of capabilities as the outcome of interactions among multiple resources (Makadok, 2001). The alternative model achieved good fit as well $\left(\chi^{2}(86)=100.76, p>.05, \mathrm{CFI}=.991, \mathrm{TLI}=.989, \mathrm{RMSEA}=.022, \mathrm{SRMR}=.041\right)$. Comparison with the hypothesized model revealed a significant improvement in model fit $\left(\Delta \chi^{2}{ }_{(1)}\right.$ $=6.29, \mathrm{p}<.05)$, indicating that the partial mediation model is a better fit to the data.

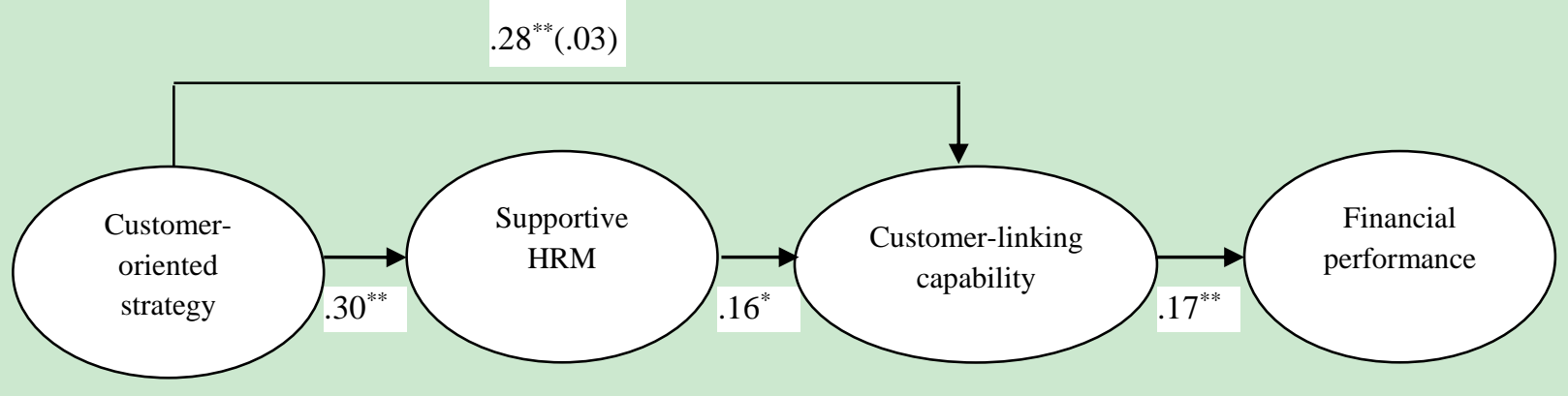

Figure 1. Results of structural equation modelling of the Chinese sample

Notes: $N=349$. Standardized estimates are reported. The coefficient in the parenthesis is the indirect effect of customer-oriented strategy on customer-linking capability mediated by supportive HRM. 


\section{HRM and Strategy Implementation}

${ }^{* *} p<.01, \stackrel{*}{p}<.05$, two-tailed.

The standardized path estimates were summarized in Figure 1. Hypothesis 1 proposed that customer-oriented strategy is positively related to customer-linking capability. Hypothesis 2 proposed that supportive HRM mediates this relationship. It was found that customer-oriented strategy was positively related to supportive $\operatorname{HRM}(\beta=.30, p<.01)$ and customer-linking capability $(\beta=.28, \mathrm{p}<.01)$. Supportive HRM was positively related to customer-linking capability $(\beta=.16, p<.05)$. Consistent with Hypothesis 1 , the total effect of customer-oriented strategy on customer-linking capability was $.32(\mathrm{p}<.01)$. To test the proposed mediating effect of supportive HRM in Hypothesis 2 we used the bootstrapping method. We resampled 1,000 times and obtained the indirect effect estimate and its confidence interval. A positive indirect effect of customer-oriented strategy on customer-linking capability mediated by supportive HRM was found $(b=.03, \mathrm{CI}=.002, .079, \alpha=.05)$. Thus, the indirect effect of customer-oriented strategy on customer-linking capability through supportive HRM accounted for $9.38 \%$ of the total effect. Because the direct effect was significant $(\beta=.28, \mathrm{p}<.01)$, a partial mediation of supportive HRM was supported.

In support of Hypothesis 3, customer-linking capability was positively related to the financial performance perceived by the marketing managers $(\beta=.17, p<.01)$. Hypothesis 4 proposed that customer-linking capability mediates the relationship between supportive HRM and financial performance. The 1,000 times bootstrapping results showed that this hypothesis received support at .10 level $(b=.04, \mathrm{CI}=.004, .102, \alpha=.10)$. Thus, Hypothesis 4 received marginal support.

\section{Study 1 Discussion}




\section{HRM and Strategy Implementation}

The results of Study 1 provide initial support for our hypotheses, demonstrating the supporting role of HRM in strategy implementation and enhancing financial performance reported by the marketing managers. Although encouraging, this study has potential limitations. Researchers sampled the Chinese firms based on their size and industry. However, these two pieces of information were not recorded in the final dataset. Although the financial performance was in relative to a firm's main competitors that likely reside in the same industry and have similar size, the lack of this information prevents us from statistically controlling for these two variables. Moreover, the study in China begs the question whether the results obtained are generalizable to another transitional economy. To strengthen the confidence in the results of Study 1 and increase its external validity we replicate this study in another transitional economyHungary.

\section{Study 2 Methods}

Hungary is another transitional economy that has undergone dramatic transition in the last two decades. After the downfall of Soviet Union in 1989, Hungary entered a post-communist era. Although different from China in many aspects, such as culture, the political systems and the accesses to markets, an important similarity is that Hungary also experienced the transition from a command to market economy. The Hungarian environmental landscape is marked by turbulent shifts, such as fluctuating economic growth rates and unemployment rate, which have translated themselves into changing customer needs (Hooley et al., 2000; Hooley et al., 2003). We expect that Hungarian firms would also have to rely on customer relationships to retain customers and capture changes in the market.

\section{Sample and data collection procedure}


HRM and Strategy Implementation

Data in Hungary was collected in a similar procedure as in China, coordinated by a Hungarian academic. A similar sampling frame was adopted. Questionnaires were returned by 510 firms, with a response rate of $21 \%$. Excluding firms with many missing data, the final sample included 465 firms. Among them 171 firms were small firms, 226 were medium firms and 68 were large firms. Firms in the business services sector make $19.6 \%$ of the sample, followed by firms in consumer services sector (17.0\%), fast moving consumer goods (15.5\%), materials and components (11.8\%), consumer durables (6.7\%) and capital industrial equipment $(3.0 \%)$. The rest of the sampled firms reside in other industries.

\section{Measures}

The same measures were used as in China. Translation from and backtranslation into English were conducted. The Cronbach's alpha for customer-oriented strategy was .82, for supportive HRM was .67, for customer-linking capability was .85 and for financial performance was .91 . We controlled for size and industry of the firms. Harman's single-factor test was performed on the items of the four latent constructs to test for common method variance. Four factors emerged and the first factor explained $27.61 \%$ of the total variance. The marker variable technique revealed that the smallest correlation between the pricing activities items and the supportive HRM items was .01 and non-significant. Therefore, common method variance is unlikely to inflate the relationships.

To assure that the results in the two countries are comparable, we tested the measurement equivalence of the latent constructs in the two countries (Cheung and Rensvold, 2002). First, we tested the CFAs of the four constructs in Hungary. The fit indexes indicated that the four-factor measurement model achieved acceptable fit $\left(\chi^{2}{ }_{(84)}=217.93, \mathrm{p}<.01, \mathrm{CFI}=.952, \mathrm{TIL}=.940\right.$, 


\section{HRM and Strategy Implementation}

RMSEA $=.059, \mathrm{SRMR}=.045)$. All indicators loaded on their respective constructs at the .001 level. The one-factor model was significantly worse than the four-factor model $\left(\chi^{2}(90)=1,828.57\right.$, $\left.\mathrm{p}<.01, \mathrm{CFI}=.374, \mathrm{TIL}=.270, \mathrm{RMSEA}=.207, \mathrm{SRMR}=.148, \Delta \chi_{(6)}^{2}=1,610.64, \mathrm{p}<.01\right)$. This provided evidence to the convergent and discriminant validity of the constructs. Combined with Chinese data, we tested configural invariance in a multigroup nested model. The results of this test $\left(\chi^{2}{ }_{(168)}=258.76, \mathrm{CFI}=.974, \mathrm{TLI}=.967, \mathrm{RMSEA}=.04, \mathrm{SRMR}=.04\right)$ showed that the constructs were tapping into the same content of domains in the two countries (Vandenberg and Lance, 2000). Constraining the factor loadings of the constructs to be equal across two samples, the fit indexes of metric equivalence model were $\chi_{(177)}^{2}=269.46, \mathrm{CFI}=.973, \mathrm{TLI}=.968$, $\mathrm{RMSEA}=.04, \mathrm{SRMR}=.05$. Both $\Delta \mathrm{CFI}$ and $\Delta \mathrm{TLI}(\Delta \mathrm{CFI}=.001, \Delta \mathrm{TLI}=.001)$ were below the cut-off value of .01 (Cheung and Rensvold, 2002). Therefore, we confirmed that metric equivalence was established. The comparability of Chinese and Hungarian data was warranted.

\section{Study 2 Results}

Table 2 presents the descriptive statistics, zero-order correlations, and scale reliabilities of the variables in the Hungarian sample. Customer-oriented strategy was positively related to supportive HRM $(\mathrm{r}=.39, \mathrm{p}<.01)$, customer-linking capability $(\mathrm{r}=.24, \mathrm{p}<.01)$ and financial performance $(\mathrm{r}=.10, \mathrm{p}<.05)$. Supportive HRM was positively related to customer-linking capability $(\mathrm{r}=.28, \mathrm{p}<.01)$ and financial performance $(\mathrm{r}=.12, \mathrm{p}<.05)$. Customer-linking capability was positively related to financial performance $(r=.16, p<.01)$. Firm size was not related to any of the four constructs. Firm industry was related to customer-oriented strategy and customer-linking capability. 
Table 2 Summary statistics, zero-order correlations, and reliabilities for the Hungarian sample

\begin{tabular}{|c|c|c|c|c|c|c|c|c|c|c|c|c|c|}
\hline Variable & Mean & SD & 1 & 2 & 3 & 4 & 5 & 6 & 7 & 8 & 9 & 10 & 11 \\
\hline 1.Customer-oriented strategy & 4.99 & 1.13 & $(.82)$ & & & & & & & & & & \\
\hline 2. Supportive HRM & 3.29 & .65 & $.39^{* *}$ & $(.67)$ & & & & & & & & & \\
\hline 3. Customer-linking capability & 3.82 & 69 & $.24^{* *}$ & $.28^{* *}$ & $(.85)$ & & & & & & & & \\
\hline 4. Financial performance & 3.60 & 1.05 & $.10^{*}$ & $.12^{*}$ & $.16^{* *}$ & $(.91)$ & & & & & & & \\
\hline 5. Medium & .49 & .50 & -.07 & -.05 & .05 & -.00 & & & & & & & \\
\hline 6. Large & .15 & .35 & .02 & .02 & -.04 & .03 & $-.40^{* *}$ & & & & & & \\
\hline 7. FMCG & .15 & .36 & -.08 & -.06 & $-.16^{* *}$ & -.00 & .01 & .01 & & & & & \\
\hline 8. $\mathrm{MaC}$ & .12 & .32 & -.02 & .04 & -.05 & -.03 & .04 & -.00 & $-.16^{* *}$ & & & & \\
\hline 9. CIE & .03 & .17 & .00 & .00 & -.05 & .05 & -.02 & -.00 & -.08 & -.07 & & & \\
\hline 10. Business services & .20 & .40 & .06 & .00 & .06 & -.03 & -.09 & -.02 & $-.21^{* *}$ & $-.18^{* *}$ & -.09 & & \\
\hline 11. Consumer services & .17 & .38 & $.14^{* *}$ & .04 & .00 & .05 & $-.10^{*}$ & .07 & $-.19^{* *}$ & $-.17^{* *}$ & -.09 & $-.22^{* *}$ & \\
\hline 12. Others & .23 & .42 & $-.11^{*}$ & -.05 & .06 & -.02 & $.12^{* *}$ & -.06 & $-.24^{* *}$ & $-.20^{* *}$ & $-.10^{*}$ & $-.27^{* *}$ & $-.25^{* *}$ \\
\hline
\end{tabular}

Notes: $\mathrm{N}=465$.

Internal reliabilities (Cronbach's Alpha) for the constructs are given in parentheses on the diagonal.

Medium = medium size, large = large size;

FMCG = fast moving consumer goods industry, $\mathrm{MaC}=$ materials and components industry, $\mathrm{CIE}=$ capital industrial equipment

industry, Business services $=$ business services industry, Consumer services $=$ consumer services industry, Others $=$ other industries

${ }^{* *} \mathrm{p}<.01,{ }^{*} \mathrm{p}<.05$, two-tailed. 
Structural modelling results suggested that the hypothesized model with firm size and industry as control variables fitted the data well: $\left(\chi^{2}(181)=282.89, \mathrm{p}<.05, \mathrm{CFI}=.964, \mathrm{TLI}\right.$ $=.955, \mathrm{RMSEA}=.035, \mathrm{SRMR}=.043)$. The alternative model with HRM partially mediating the relationship between customer-oriented strategy and customer-linking capability achieved acceptable fit, too $\left(\chi^{2}(180)=278.46, \mathrm{p}<.05, \mathrm{CFI}=.965, \mathrm{TLI}=.956, \mathrm{RMSEA}=.035, \mathrm{SRMR}\right.$ $=.041)$. The chi-square difference test showed that the improvement in fit was significant $(\Delta \chi(1)$ $=4.43, \mathrm{p}<.05)$. Hence, similarly to the Chinese sample the alternative partial mediation model fitted the data better. It was noted that firm size and industry were only marginally related to customer-linking capability: medium-sized firms rated themselves as possessing higher customer-linking capability $(\beta=.10, \mathrm{p}<.10)$. Firms from consumer services industry and capital industrial equipment industry reported a lower customer-linking capability $(\beta=-.14, p<.10 ; \beta=$ $-.27, \mathrm{p}<.10$, respectively). Therefore, size and industry had no substantial effect on the relationships in the model.

\section{$.13^{*}(.10)$}

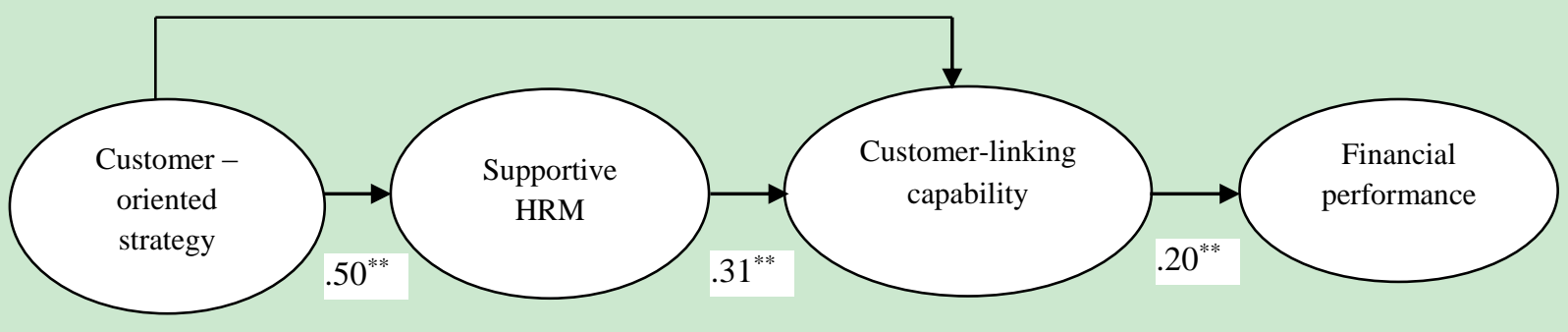

Figure 2. Results of structural equation modelling of the Hungarian sample

Notes: $N=465$. Standardized estimates are reported. The coefficient in the parenthesis is the indirect effect of customer-oriented strategy on customer-linking capability mediated by HRM, after controlling for firm size and industry.

${ }^{* *} p<.01,{ }^{*} p<.05$, two-tailed. 


\section{HRM and Strategy Implementation}

The standardized path estimates between the latent constructs were summarized in Figure 2. Customer-oriented strategy was positively related to $\operatorname{HRM}(\beta=.50, p<.01)$ and customerlinking capability $(\beta=.13, \mathrm{p}<.05)$. HRM was positively related to customer-linking capability $(\beta=.31, \mathrm{p}<.01)$. The total effect of customer-oriented strategy on customer-linking capability was $.19(\mathrm{p}<.01)$. Hence Hypothesis 1 proposing that a firm's customer-oriented strategy is positively related to its customer-linking capability received supported. To test the mediation effect of supportive HRM proposed in Hypothesis 2, we resampled 1,000 times and obtained the indirect effect and its confidence interval. We found a positive indirect effect of customeroriented strategy on customer-linking capability mediated by supportive HRM $(b=.10, \mathrm{CI}$ $=.045, .180, \alpha=.05)$, accounting for $52.63 \%$ of the total effect. Because the direct effect of customer-oriented strategy on customer-linking capability was significant $(\beta=.13, \mathrm{p}<.05)$, a partial mediation of supportive HRM was supported.

A positive relationship between customer-linking capability and financial performance perceived by the marketing managers $(\beta=.20, \mathrm{p}<.01)$ rendered support to Hypothesis 3 . Hypothesis 4 which proposed that customer-linking capability mediated the relationship between HRM and financial performance received support from 1,000 times bootstrapping results $(b=.10$, $\mathrm{CI}=.042, .207, \alpha=.05)$. So the results of study 1 were all replicated in the Hungarian sample.

To be consistent with Study 1, we reran the results without the control variables. None of the relationships were significantly changed. The relationship between supportive HRM and customer-linking capability decreased slightly from .31 to .30 . The relationship between customer-linking capability and financial performance decreased slightly from .20 to .18. The other two path estimates remained unchanged. The indirect effect of customer-oriented strategy on customer-linking capability through the mediation of HRM was $.10 . \mathrm{CI}=.047, .188, \alpha=.05$. 


\section{HRM and Strategy Implementation}

The indirect effect of HRM on financial performance through customer-linking capability was .09. $\mathrm{CI}=.036, .193, \alpha=.05$.

\section{Study 2 Discussion}

With the successful replication of all findings of Study 1 in the Hungarian sample, the external validity of our theoretical framework was strengthened. The successful replication also suggests that our findings are not likely to be based on chance or sampling error. The trivial effects of size and industry in Study 2 indicate that the results in Study 1 are likely to be robust. Although China and Hungary are different in many ways, the environment of both countries is characterized by a transitional nature. Marketing research has suggested that in turbulent markets firms need to be particularly sensitive to market changes (Hooley et al., 2000; Slater and Narver, 1994). This might explain the significant mediating effect of customer-linking capability in these two countries.

\section{General Discussion}

\section{Theoretical contributions and practical implications}

Drawing on the organizational capabilities literature, we developed and tested a model of how HRM supported firms' customer-oriented strategy and contributed to their financial performance through developing customer-linking capability. Data collected from two transitional economies supported our theoretical framework.

At a broad level, this study contributes to the literature on strategy implementation. Using customer-linking capability as an indicator of the implementation of customer-oriented strategy, this study shows that the ability of strategy implementation is, in itself, a valuable resource 


\section{HRM and Strategy Implementation}

(Barney, 2001). Heterogeneity in customer-linking capability accounted for significant variance in perceived firm performance. Hence, although firms may choose the same positioning strategy, it is the difference in implementation that results in difference in performance. The contribution of supportive HRM to the development of customer-linking capability and thereby to organizational financial performance corroborates the statement of Becker and Huselid (2006) that the contribution of HRM to performance lies in its support for strategy implementation.

Furthermore, the insights on "value" in strategy research suggest that value is created within organizations by the actions of organization members, but captured at the point of sale when customers are willing to pay for the products or services (Bowman and Ambrosini, 2000). Thus, while profit differences between firms derive from the performance of internal human resources, customer-facing capabilities must be developed to capture the profits. By integrating HRM and customer-linking capability, this research provides a more complete account of firms' financial performance.

Last but not least, this study builds on the strategy, marketing and HRM literature and adopts an interdisciplinary perspective. The three streams of literature complement each other, so we are able to contribute to each of these three fields. As to the field of strategy, this study advances our understanding of strategy implementation from the perspective of HRM. Adding to the marketing literature, we have clarified the nature of customer-linking capability as a dual-purpose capability by drawing on the strategy research. Moreover, marketing researchers admit that understanding the relationship between customers and other stakeholders such as employees have been neglected in the mainstream marketing literature (Payne and Holt, 2001). This study investigates the relationship between serving customers and taking care of employees and addresses this limitation. Furthermore, HR scholars recognize that there is a tendency for HR researchers to 


\section{HRM and Strategy Implementation}

confine their attention within the HR architecture which includes HR policies, practices, and employee outcomes (Becker and Huselid, 2006). This study overcomes this shortcoming by introducing customer-facing capability. Thus, the interdisciplinary perspective has enabled us to contribute to multiple fields and speak to a wider audience.

In addition to the theoretical contributions, this study carries useful practical implications. The most important message of this study is that HRM practices in an organization should be aligned with its strategy to foster the strategy implementation. Organizations rely on employees to enact strategic goals. "Fit" HRM practices encourage employee attitudes and behaviours required for critical organizational capabilities which enable the strategy realization (Becker and Huselid, 2006). This study specifically spells out the HRM practices that are aligned with a customer-oriented strategy. It suggests that HRM practices taking care of employees would benefit customers and ultimately benefit the organization. Indeed, J. Willard Marriott, the founder of the Marriott Corporation, said that "take care of your people and they will take care of your customers". Hence, managers shall treat their employees as internal customers (Heskett et al., 2003) and attend to their needs. Correspondingly, organizations may have employee satisfaction as an important indicator of managers' performance.

Another important message is that establishing close customer relationships is imperative to satisfying customers. For firms in fast-changing environment, the importance of customer relationships may be all the more salient due to its role in capturing changing customer needs (Hooley et al., 2000). Although firms heavily invest in customer relationship management technology to collect customer data, the human factors in managing customer relationship shall not be ignored (Davenport et al., 2001; Payne and Frow, 2005). In fact, it is the very human 
HRM and Strategy Implementation

factors, such as a shared understanding of good customer-linking practices across different levels of organization, that make this capability particularly difficult to imitate.

\section{Limitations and Avenues for Future Research}

Given these important theoretical and practical implications, this research may serve as a starting point for significant future enquiry. First of all, marketing researchers have advocated the integration of all organizational functions to build market-driven organizations (Vargo and Lusch, 2004), because such integration will produce synergies and leverage the effect of each function. It would be theoretically relevant for future research to explore the interplay between HRM and other functions in enhancing market-related capabilities. This would necessarily entail an interdisciplinary approach, which has the potential to make novel and insightful contributions.

Second, we only focused on customer-linking capability due to its central role for customeroriented strategy. However, organizational capabilities are of infinite variety (Eisenhardt and Martin, 2000) and their antecedents may vary depending on the specific type of capabilities. Because a substantial part of customer-linking capability is forged in the interactions between employees and customers and it is people-oriented in nature, HRM may exert a larger influence. To other capabilities HRM may be less relevant. Nevertheless, most organizational capabilities are constituted by routines in which people interact in established ways (Cyert and March, 1963). Hence, we expect that HRM plays a role in the establishment of most organizational capabilities.

Third, the single informant and cross-sectional approach in data collection potentially leads to some limitations. One of them is the common method variance (Podsakoff et al., 2003). Although statistical tests find that this is less likely a concern, future researchers should address this limitation in their research design. For example, multiple respondents could be asked to 


\section{HRM and Strategy Implementation}

report on the constructs. Multiple respondents rating the same construct such as HRM can also reveal the variation of its adoption within an organization (Lepak and Snell, 2002). For us, however, it was a trade-off between multiple respondents and sample size due to resource constraints. To increase the statistical power, we chose to have a larger and richer sample. Alternatively, this limitation could be addressed by using objective performance data. Furthermore, the cross-sectional nature of the data means that customer-linking capability in this study measures the outcome of strategy implementation instead of the process. Longitudinal studies would allow researchers to examine the whole strategy implementation process and rule out reverse causality.

Finally, the supportive HRM measure in this study included only developmental performance appraisals and communication practices, although other HRM practices such as employee training and welfares can convey organizational supportiveness as well (Takeuchi, Chen and Lepak, 2009). Future studies could include more HRM practices to construct a more comprehensive measure of supportive HRM. The findings of this study nonetheless indicate that a relative small set of HRM practices have the potential to yield a high return in terms of understanding customers.

In overall, our study examines the implication of customer-oriented strategy on HRM and answers the call of Becker and Huselid (2006) for a fuller integration of strategic capabilities into strategic HRM theory. It lends support to the organizational capabilities theory and reveals that customer-linking capability can be a source of firm's competitive advantage. Our study thus makes contributions to the strategy management, HRM and marketing literatures and offers practical implications for firms striving for excellence in serving their customers. 


\section{HRM and Strategy Implementation}

\section{References}

Allen, D. G., L. M. Shore and R. W. Griffeth (2003). 'The role of perceived organizational support and supportive human resource practices in the turnover process', Journal of management, 29, pp. 99118.

Ambrosini, V., C. Bowman and N. Collier (2009). 'Dynamic capabilities: An exploration of how firms renew their resource base', British Journal of Management, 20, pp. S9-S24.

Amit, R. and P. J. Schoemaker (1993). 'Strategic assets and organizational rent', Strategic management journal, 14, pp. 33-46.

Anderson, J. C. and D. W. Gerbing (1988). 'Structural equation modeling in practice: A review and recommended two-step approach', Psychological Bulletin, 103, pp. 411-423.

Bae, J. and J. J. Lawler (2000). 'Organizational and HRM strategies in Korea: Impact on firm performance in an emerging economy', Academy of Management Journal, 43, pp. 502-517.

Barney, J. (1991). 'Firm Resources and Sustained Competitive Advantage', Journal of management, 17, pp. 99-120.

Barney, J. B. (2001). 'Is the resource-based "view" a useful perspective for strategic management research? Yes', Academy of management review, 26, pp. 41-56.

Barney, J. B. and P. M. Wright (1998). 'On becoming a strategic partner: The role of human resources in gaining competitive advantage', Human Resource Management, 37, pp. 31-46.

Becker, B. E. and M. A. Huselid (2006). 'Strategic human resources management: where do we go from here?', Journal of management, 32, pp. 898-925.

Berry, L. L. (1983). 'Relationship marketing '. In: L. L. Berry, L. Shostack and G. D. Upah (eds.), Emerging Perspectives of Services Marketing. pp. 25-28. Chicago: American Marketing Association.

Boswell, W. R. and J. W. Boudreau (2002). 'Separating the developmental and evaluative performance appraisal uses', Journal of Business and Psychology, 16, pp. 391-412.

Bowman, C. and V. Ambrosini (2000). 'Value creation versus value capture: Towards a coherent definition of value in strategy', British Journal of Management, 11, pp. 1-15.

Brislin, R. W. (1970). 'Back-translation for cross-cultural research', Journal of Cross-Cultural Psychology, 1, pp. 185-216.

Buller, P. F. and G. M. McEvoy (2012). 'Strategy, human resource management and performance: Sharpening line of sight', Human Resource Management Review, 22, pp. 43-56.

Camps, J. and R. Luna-Arocas (2012). 'A matter of learning: How human resources affect organizational performance', British Journal of Management, 23, pp. 1-21.

Chadwick, C. and P. Cappelli (1999). 'Alternatives to generic strategy typologies in strategic human resource management', Research in Personnel and Human Resource Management, 4, pp. 1-30.

Chadwick, C. and A. Dabu (2009). 'Human resources, human resource management, and the competitive advantage of firms: Toward a more comprehensive model of causal linkages', Organization Science, 20, pp. 253-272.

Cheung, G. W. and R. B. Rensvold (2002). 'Evaluating goodness-of-fit indexes for testing measurement invariance', Structural Equation Modelling, 9, pp. 233-255.

Chuang, C.-H. and H. Liao (2010). 'Strategic human resource management in service context: Taking care of business by taking care of employees and customers', Personnel Psychology, 63, pp. 153-196.

Cyert, R. M. and J. G. March (1963). A Behavioral Theory of the Firm, Prentice-Hall, Englewood Cliffs, NJ.

Danneels, E. (2008). 'Organizational antecedents of second-order competences', Strategic management journal, 29, pp. 519-543.

Davenport, T. H., J. G. Harris and A. K. Kohli (2001). 'How do they know their customers so well?', Sloan Management Review, 42, pp. 63-74. 


\section{HRM and Strategy Implementation}

Day, G. S. (1994). 'The capabilities of market-driven organizations', Journal of Marketing, 58, pp. 37-52.

Denrell, J., N. Arvidsson and U. Zander (2004). 'Managing knowledge in the dark: An empirical study of the reliability of capability evaluations', Management science, 50, pp. 1491-1503.

Deshpandé, R., J. U. Farley and F. E. Webster Jr (1993). 'Corporate culture, customer orientation, and innovativeness in Japanese firms: a quadrad analysis', Journal of Marketing, pp. 23-37.

Easterby-Smith, M., M. A. Lyles and M. A. Peteraf (2009). 'Dynamic capabilities: current debates and future directions', British Journal of Management, 20, pp. S1-S8.

Einsenberger, R., J. Cummings, S. Aemeli and P. Lynch (1997). 'Perceived organizational support, discretionary treatment, and job satisfaction', Journal of Applied Psychology, 82, pp. 812-820.

Eisenhardt, K. and J. Martin (2000). 'Dynamic capabilities: What are they?', Strategic management journal, 21, pp. 1105-1121.

Gibbons, R. and R. Henderson (2012). 'Relational contracts and organizational capabilities', Organization science, 23, pp. 1350-1364.

Greenley, G. E. and G. R. Foxall (1997). 'Multiple stakeholder orientation in UK companies and the implications for company performance', Journal of Management Studies, 34, pp. 259-284.

Greenley, G. E., G. J. Hooley and J. M. Rudd (2005). 'Market orientation in a multiple stakeholder orientation context: implications for marketing capabilities and assets', Journal of Business Research, 58, pp. 1483-1494.

Gremler, D. D., K. P. Gwinner and S. W. Brown (2001). 'Generating positive word-of-mouth communication through customer-employee relationships', International Journal of Service Industry Management, 12, pp. 44-59.

Grönroos, C. (1994). 'From marketing mix to relationship marketing: Towards a paradigm shift in marketing', Asia-Australia Marketing Journal, 2, pp. 9-29.

Guenzi, P. and G. Troilo (2006). 'Developing marketing capabilities for customer value creation through marketing-sales integration', Industrial Marketing Management, 35, pp. 974-988.

Gummesson, E. (1994). 'Broadening and specifying relationship marketing', Asia-Australia Marketing Journal, 2, pp. 31-43.

Guthrie, J. P., C. S. Spell and R. O. Nyamori (2002). 'Correlates and consequences of high involvement work practices: the role of competitive strategy', International Journal of Human Resource Management, 13, pp. 183-197.

Harker, M. J. and J. Egan (2006). 'The past, present and future of relationship marketing', Journal of Marketing Management, 22, pp. 215-242.

Harter, J. K., F. L. Schmidt and T. L. Hayes (2002). 'Business-unit-level relationship between employee satisfaction, employee engagement, and business outcomes: a meta-analysis', Journal of Applied Psychology, 87, pp. 268-279.

Helfat, C. E., S. Finkelstein, W. Mitchell, M. A. Peteraf, H. Singh, D. J. Teece and S. Winter, G. (2007). Dynamic Capabilities: Understanding Strategic Change in Organizations, Blackwell Publishing, Malden, MA.

Helfat, C. E. and M. A. Peteraf (2003). 'The dynamic resource-based view: capabilities lifecyles', Strategic management journal, 24, pp. 997-1010.

Helfat, C. E. and S. Winter, G. (2011). 'Untangling dynamic and operational capabilities: Strategy for the (n)ever-changing world', Strategic management journal, 32, pp. 1243-1250.

Heskett, J. L., W. E. Sasser and L. A. Schlesinger (2003). The Value Profit Chain: Treat Employees Like Customers and Customers Like Employees, Free Press, New York, NY.

Hong, Y., H. Liao, J. Hu and K. Jiang (2013). 'Missing link in the service profit chain: A meta-analytic review of the antecedents, consequences, and moderator of service climate', Journal of Applied Psychology, 98, pp. 237-267.

Hooley, G., T. Cox, J. Fahy, D. Shipley, J. Beracs, K. Fonfara and B. Snoj (2000). 'Market orientation in the transition economies of central Europe: Tests of the Narver and Slater market orientation scales', Journal of Business Research, 50, pp. 273-285. 


\section{HRM and Strategy Implementation}

Hooley, G. J., J. Fahy, G. Greenley, J. Beracs, K. Fonfara and B. Snoj (2003). 'Market orientation in the service sector of the transition economies of central Europe', European Journal of Marketing, 37, pp. 86-106.

Hooley, G. J., G. E. Greenley, J. W. Cadogan and J. Fahy (2005). 'The performance impact of marketing resources', Journal of Business Research, 58, pp. 18-27.

Huselid, M. A., B. E. Becker and R. W. Beatty (2005). The Workforce Scorecard: Managing Human Capital to Execute Strategy, Harvard Business Press, Boston, MA.

Hutzschenreuter, T. and I. Kleindienst (2006). 'Strategy-process research: what have we learned and what is still to be explored', Journal of management, 32, pp. 673-720.

James, L. R. and J. M. Brett (1984). 'Mediators, moderators, and tests for mediation', Journal of Applied Psychology, 69, p. 307.

Kim, A. and C. Lee (2012). 'How does HRM enhance strategic capabilities? Evidence from the Korean management consulting industry', International Journal of Human Resource Management, 23, pp. 126-146.

Krasnikov, A., S. Jayachandran and V. Kumar (2009). 'The impact of customer relationship management implementation on cost and profit efficiencies: evidence from the US commercial banking industry', Journal of Marketing, 73, pp. 61-76.

Lado, A. A. and M. C. Wilson (1994). 'Human resource systems and sustained competitive advantage: A competency-based perspective', Academy of Management Review, 19, pp. 699-727.

Lepak, D. P. and S. A. Snell (2002). 'Examining the human resource architecture: The relationships among human capital, employment, and human resource configurations', Journal of management, 28, pp. 517-543.

Lepak, D. P., R. Takeuchi, N. L. Erhardt and S. Colakoglu (2006). 'Emerging perspectives on the relationship between HRM and performance'. In: R. J. Burke and C. L. Cooper (eds.), The Human Resources Revolution: Research and Practice. Oxford, UK: Elsevier.

Levitt, T. (1969). The Marketing Mode, McGraw-Hill New York.

Liao, H. and M. Subramony (2008). 'Employee customer orientation in manufacturing organizations: Joint influences of customer proximity and the senior leadership team', Journal of Applied Psychology, 93, pp. 317-328.

Lindell, M. K. and D. J. Whitney (2001). 'Accounting for common method variance in cross-sectional research designs', Journal of Applied Psychology, 86, pp. 114-121.

Lopez-Cabrales, A., R. Valle and I. Herrero (2006). 'The contribution of core employees to organizational capabilities and efficiency', Human Resource Management, 45, pp. 81-109.

Makadok, R. (2001). 'Toward a synthesis of the resource-based and dynamic-capability views of rent creation', Strategic management journal, 22, pp. 387-401.

Mithas, S., M. S. Krishnan and C. Fornell (2005). 'Why do customer relationship management applications affect customer satisfaction?', Journal of Marketing, 69, pp. 201-209.

Morris, S. S. and S. A. Snell (2011). 'Intellectual capital configurations and organizational capability: An empirical examination of human resource subunits in the multinational enterprise', Journal of international business studies, 42, pp. 805-827.

Muthén, L. K. and B. O. Muthén (1998-2010). Mplus User's Guide, Muthén \& Muthén, Los Angeles, CA.

Nambisan, S. (2002). 'Designing virtual customer environments for new product development: Toward a theory', Academy of management review, 27, pp. 392-413.

Narver, J. C. and S. F. Slater (1990). 'The effect of a market orientation on business profitability', Journal of Marketing, 54, pp. 20-35.

Nelson, R. R. and S. Winter, G. (1982). An Evolutionary Theory of Economic Change, Belknap Press, Cambridge, MA.

Nishii, L. H., D. P. Lepak and B. Schneider (2008). 'Employee attributions of the "why" of HR practices: Their effects on employee attitudes and behaviors, and customer satisfaction', Personnel Psychology, 61, pp. 503-545. 


\section{HRM and Strategy Implementation}

Noble, C. H. (1999). 'The eclectic roots of strategy implementation research', Journal of Business Research, 45, pp. 119-134.

Noe, R. A., J. R. Hollenbeck, B. Gerhart and P. M. Wright (2005). Human Resource Management: Gaining a Competitive Advantage, McGraw-Hill, Boston.

Paauwe, J. (2004). HRM and Performance: Achieving Long-Term Viability, Oxford University Press, Oxford.

Park, H. J., T. M. Gardner and P. Wright (2004). 'HR practices or HR capabilties: which matters? Insights from the Asia Pacific region', Asia Pacific Journal of Human Resources, 42, pp. 260-273.

Payne, A. and P. Frow (2005). 'A strategic framework for customer relationship management', Journal of Marketing, 69, pp. 167-176.

Payne, A. and S. Holt (2001). 'Diagnosing customer value: Integrating the value process and relationship marketing', British Journal of Management, 12, pp. 159-182.

Podsakoff, P. M., S. B. MacKenzie, J.-Y. Lee and N. P. Podsakoff (2003). 'Common method biases in behavioral research: a critical review of the literature and recommended remedies', Journal of Applied Psychology, 88, p. 879.

Porter, M. E. (1985). Competitive Advantage: Creating and Sustaining Superior Performance, Free Press, New York, NY.

Porter, M. E. (1996). 'What is strategy?', Harvard Business Review, 74, pp. 61-78.

Prahalad, C. K. and G. Hamel (1990). 'The core competence of the corporation', Harvard Business Review, 78, pp. 79-87.

Rapp, A., K. J. Trainor and R. Agnihotri (2010). 'Performance implications of customer-linking capabilities: Examining the complementary role of customer orientation and CRM technology', Journal of Business Research, 63, pp. 1229-1236.

Rigby, D. K., F. F. Reichheld and P. Schefter (2002). 'Avoid the four perils of CRM', Harvard Business Review, 80, pp. 101-109.

Riggle, R. J., D. R. Edmondson and J. D. Hansen (2009). 'A meta-analysis of the relationship between perceived organizational support and job outcomes: 20 years of research', Journal of Business Research, 62, pp. 1027-1030.

Ruekert, R. W. (1992). 'Developing a market orientation: an organizational strategy perspective', International Journal of Research in Marketing, 9, pp. 225-245.

Salancik, G. R. and J. Pfeffer (1977). 'An examination of need-satisfaction models of job attitudes', Administrative Science Quarterly, 22, pp. 427-456.

Schneider, B. and D. E. Bowen (1985). 'Employee and customer perceptions of service in banks: Replication and extension', Journal of Applied Psychology, 70, p. 423.

Schneider, B. and D. E. Bowen (1995). Winning the Service Game, Harvard Business School Press, Boston, MA.

Schneider, B., M. G. Ehrhart, D. M. Mayer, J. L. Saltz and K. Niles-Jolly (2005). 'Understanding organization-customer links in service settings', Academy of Management Journal, 48, pp. 10171032.

Schneider, B., S. S. White and M. C. Paul (1998). 'Linking service climate and customer perceptions of service quality: Tests of a causal model', Journal of Applied Psychology, 83, pp. 150-163.

Schuler, R. S. and S. E. Jackson (1987). 'Linking competitive strategies with human resource management practices', Academy of Management Executive, 1, pp. 207-219.

Sin, L. Y. M., A. C. B. Tse, O. H. M. Yau, R. P. M. Chow and J. S. Y. Lee (2005). 'Market orientation, relationship marketing orientation, and business performance: the moderating effects of economic ideology and industry type', Journal of International Marketing, 13, pp. 36-57.

Slater, S. F. and J. C. Narver (1994). 'Does competitive environment moderate the market orientationperformance relationship?', Journal of Marketing, 58, pp. 46-55.

Smidts, A., A. T. H. Pruyn and C. B. Van Riel (2001). 'The impact of employee communication and perceived external prestige on organizational identification', Academy of Management Journal, 44, pp. 1051-1062. 


\section{HRM and Strategy Implementation}

Srivastava, R. K., T. A. Shervani and L. Fahey (1998). 'Market-based assets and shareholder value: A framework for analysis', Journal of Marketing, 62, pp. 2-18.

Storbacka, K., T. Strandvik and C. Grönroos (1994). 'Managing customer relationships for profit: the dynamics of relationship quality', International Journal of Service Industry Management, 5, pp. 21-38.

Swift, R. S. (2000). Accelerating Customer Relationships: Using CRM and Relationship Technologies, Prentice Hall, Upper Saddle River, NJ.

Takeuchi, R., G. Chen and D. P. Lepak (2009). 'Through the looking glass of a social system: Cross-level effects of the high-performance work systems on employees' attitudes', Personnel Psychology, 62, pp. 1-29.

Teece, D. J., G. Pisano and A. Shuen (1997). 'Dynamic capabilities and strategic management', Strategic management journal, 18, pp. 509-533.

Treacy, M. and F. Wiersema (1993). 'Customer intimacy and other value disciplines', Harvard Business Review, 71, pp. 84-93.

Ulrich, D. (1992). 'Strategic and human resource planning: Linking customers and employees', People and Strategy, 15, p. 47.

Vandenberg, R. J. and C. E. Lance (2000). 'A review and synthesis of the measurement invariance literature: Suggestions, practices, and recommendations for organizational research', Organizational Research Methods, 3, pp. 4-70.

Vargo, S. L. and R. F. Lusch (2004). 'Evolving to a new dominant logic for marketing', Journal of Marketing, 68, pp. 1-17.

Wall, T. D., J. Michie, M. Patterson, S. J. Wood, M. Sheehan, C. W. Clegg and M. West (2004). 'On the validity of subjective measures of company performance', Personnel Psychology, 57, pp. 95-118.

Wei, L.-Q. and C.-M. Lau (2010). 'High performance work systems and performance: The role of adaptive capability', Human Relations, 63, pp. 1487-1511.

Wernerfelt, B. (1984). 'A resource - based view of the firm', Strategic Management Journal, 5, pp. 171180.

Youndt, M. A., S. A. Snell, J. W. Dean and D. P. Lepak (1996). 'Human resource management, manufacturing strategy, and firm performance', Academy of Management Journal, 39, pp. 836866.

Zhao, Z. J. and C. Chadwick (2014). 'What we will do versus what we can do: The relative effects of unitlevel NPD motivation and capability', Strategic management journal, 35, pp. 1867-1880. 